Sains Malaysiana 49(11)(2020): 2735-2744

http://dx.doi.org/10.17576/jsm-2020-4911-12

\title{
A Tyrosine-Based Nanosensor for Rapid Sensitive Detection of Copper (II) Ions
}

(Pengesan Nano Berasaskan Tirosina untuk Pengesanan Sensitif Pantas Ion Tembaga (II))

\author{
Jiaqi Lian, PAndeng MiaO, Na li, Abdul Jamil Khan, XiAng Ji* \& Feng Zhang
}

\section{ABSTRACT}

Most of the chromophores of fluorescent peptides contain aromatic amino acids with conjugated double bonds, among which tyrosine (Y) has become the focus of researches due to its unique physicochemical (optical, redox, and metal chelation) properties. However, there are few studies on the self-assembly and polymerisation of single. This study shows that the phenol group of $Y$ can be oxidized into benzoquinone group in alkaline conditions and then undergoes polymerisation and further self-assembles into nanoparticles (NPS). The product of $\mathrm{p} Y_{\text {or }} N P$ s have a strong fuorescence emission peak at $463 \mathrm{~nm}$, and $\mathrm{Cu}^{2+}$ can spontaneously bind to it and dramatically quench their fluorescence. Based on these findings, we developed a rapid, sensitive and specific nanosensor for detecting $\mathrm{Cu}^{2+}$. When the concentration of $\mathrm{Cu}^{2+}$ is within the range of $40 \mu \mathrm{M}-1 \mathrm{mM}$, we can obtain a good linear correlation between the fluorescence intensity of $\mathrm{p} Y$ ox NPs and the concentration of copper ions, and the limit of detection (LOD) is determined to $37.26 \mu \mathrm{M}$. In comparison to other modern methods for sensing $\mathrm{Cu}^{2+}$, this method has advantages of simplicity of material synthesis, low cost, robust and rapid in sensing reaction, so we envision a good prospect for $\mathrm{Cu}^{2+}$ detection applications in both bulk and harsh environments.

Keywords: Copper ion; fluorescence quenching; oxidation; polymerisation; tyrosine

\section{ABSTRAK}

Kebanyakan kromofor peptida pendarfluor mengandungi asid amino aromatik dengan ikatan berganda konjugasi, antaranya tyrosin (Y) telah menjadi tumpuan penyelidikan kerana ciri unik fizikokimianya (optik, redoks dan pengkelatan logam). Walau bagaimanapun, terdapat beberapa kajian mengenai pemasangan diri dan pempolimeran tunggal Y. Dalam kajian ini, kumpulan fenol Y boleh dioksidakan kepada kumpulan benzoquinon dalam keadaan alkali dan kemudian menjalani pempolimeran dan seterusnya menyambung diri ke nanozarah (NPs). pY NPs produk mempunyai puncak pelepasan pendarfluor yang kuat pada $463 \mathrm{~nm}$ dan $\mathrm{Cu}^{2+}$ secara spontan dapat mengikat mereka dan secara mendadak memadamkan pendarfluor mereka. Berdasarkan penemuan ini, kami membangunkan pengesan nano pesat, sensitif dan khusus untuk mengesan $\mathrm{Cu}^{2+}$. Apabila kepekatan $\mathrm{Cu}^{2+}$ berada dalam julat $40 \mu \mathrm{M}-1 \mathrm{mM}$, kita boleh mendapatkan korelasi linear yang baik antara keamatan pendarfluor $\mathrm{p} Y$ or $N P$ s dan kepekatan ion tembaga, dan had pengesanan (LOD) ditentukan kepada $37.26 \mu \mathrm{M}$. Berbanding dengan kaedah moden yang lain untuk mengesan $\mathrm{Cu}^{2+}$, ini memperlihatkan kelebihan dalam kesederhanaan sintesis bahan, kos rendah dan mudah diperoleh, cepat dan pantas dalam reaksi penderiaan, jadi kami membayangkan prospek yang baik untuk aplikasi pengesanan $\mathrm{Cu}^{2+}$ dalam persekitaran pukal dan mencabar.

Kata kunci: Ion tembaga; pelindapkejutan pendarfluor; pengoksidaan; pempolimeran; tirosina

\section{INTRODUCTION}

Copper is one of the most important microelements in human body (Nieder et al. 2018). It mainly participates in the composition of enzymes in the organism and regulates the metabolism of both lipid and sugar (Baker et al. 2017; Kusunuru et al. 2013). However, excessive copper can cause poisoning (Bulcke et al. 2017).

Moreover, few mental illnesses such as schizophrenia and Alzheimer's disease (AD) are also related to copper ions $\left(\mathrm{Cu}^{2+}\right)$ (Brewer 2012; Yu et al. 2018). At present, the detection technology of $\mathrm{Cu}^{2+}$ mainly includes atomic absorption spectroscopy, colorimetry, fluorescence quenching and electrochemiluminescence analysis (Ghasemian et al. 2012). Among them, fluorescencebased methods attract great interest from researchers due to their outstanding advantages of fast response and high sensitivity. The traditional fluorescence-based methods mainly make use of organic dyes, and metal nanoclusters and inorganic quantum dots as chromophores (Li et al. 2017). Most of these chromophores are 
difficult to synthesize, unstable or toxic, and are not environmentally-friendly (or biocompatible). Contino et al. (2016) used unoxidized L-tyrosine (Y)-coated silver nanoparticles (AgNPs) to detect $\mathrm{Cu}^{2+}$; however, the instability of AgNPs significantly limits its applications due to easy oxidation. Xu et al. (2010) used colorimetric method to detect $\mathrm{Cu}^{2+}$ based on the gold nanoparticle (AuNP)-nucleotide (single strand) complex, in which three designed single-strand DNA can co-assemble to nanostructures, whose melting temperature $(\mathrm{Tm})$ will increase with addition of $\mathrm{Cu}^{2+}$, and this alteration is linear within a certain range of $\mathrm{Cu}^{2+}$ concentrations. However, this approach requires a time-consuming preparation. White and Holcombe (2007) used the Fmoc-based solidphase synthesis method to produce peptides modified with a fluorescence chromophore of dansyl chloride, which can detect $\mathrm{Cu}^{2+}$ with their metal ion chelation capacity and then quench the fluorescence upon binding, however, the peptide synthesis is costly. Therefore, it is necessary to develop a new low-cost, simple and environment-friendly method for $\mathrm{Cu}^{2+}$ detection.

Peptide-based nanostructures are sensitive to the environmental conditions such as ionic strength, and temperature. Because of weak-intermolecular interactions such as van der Waals force, hydrophobic interaction, $\pi-\pi$ stacking, electrostatic interaction, ionic and hydrogen bonds, their conformational changes will eventually cause the fluctuations of its inherent functionality, which usually is used to design sensors (Parmar et al. 2016). Hence, it would be great to construct fluorescent nanostructures using peptides or amino acids. However, to emit fluorescence in a visible light region is still a big challenge with peptide-based nanostructures. This is because natural amino acids such as phenylalanine $(\mathrm{F})$, $\mathrm{Y}$ and tryptophan $(\mathrm{W})$, can only emit fluorescence in the ultraviolet region (Teale \& Weber 1957).
Previous studies have found that self-assembly of aromatic amino acids or short peptides can emit highquantum-yield fluorescence in the visible light region (Pinotsi et al. 2016), in which probabilities for photoradiation transition of electrons has been enhanced by decreasing the inactivation pathways (like thermal conversions) of activated electrons on the benzene ring, and meanwhile, the self-assembly enlarges the conjugated electron structures (Guo et al. 2019). Among these amino acids, $\mathrm{Y}$ has become the focus of researches because of its unique physicochemical properties and its importance in biological metabolism. For example, Y forms catecholamines under the action of enzymes (such as dopamine hydroxylase) in vivo, which has been found closely related to a mental disorder called attention deficit hyperactivity disorder (ADHD) in children (Bergwerff et al. 2016). Y can also form melanin under the action of tyrosinase, and the lack of tyrosinase can cause albinism (Kamaraj \& Purohit 2014). At present, there have been many reports on the effects of nitration of $\mathrm{Y}$ and the $\mathrm{Y}$ residues of proteins, but few studies on the self-assembly and polymerisation of single $\mathrm{Y}$ molecules (Bartesaghi \& Radi 2018).

In this study, aiming to build a biocompatible nanosensor for $\mathrm{Cu}^{2+}$ detection, we try to employ both polymerisation and self-assembly to produce fluorescent nanostructures using only $\mathrm{Y}$, and further test it for $\mathrm{Cu}^{2+}$ sensing (Lin et al. 2011). In practice, we found that $Y$ can be oxidized to its oxidized state $\mathrm{Y}_{\mathrm{ox}}$ in alkaline solutions and further form polymer nanoparticles $\left(p \mathrm{Y}_{\mathrm{ox}} \mathrm{NPs}\right)$ by both polymerisations of $Y_{o x}$ and self-assembly, and the $p \mathrm{Y}_{\text {ox }} \mathrm{NPs}$ can emit stable and strong fluorescence, which can apply to sense $\mathrm{Cu}^{2+}$ due to their efficient quenching action (Figure 1).

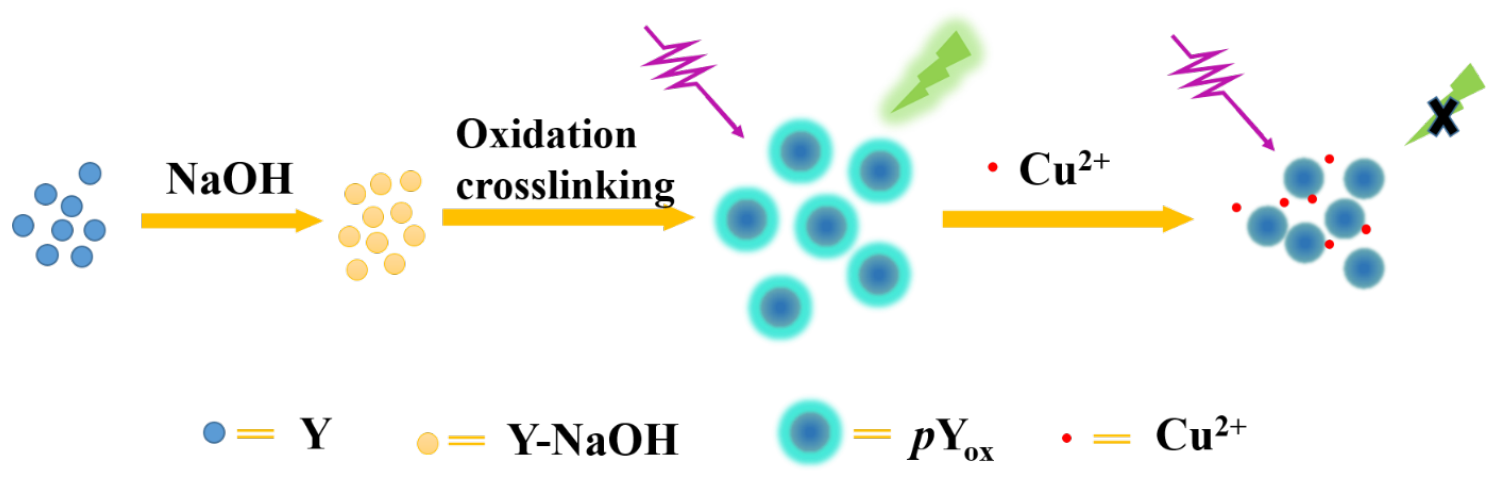

FIGURE 1. A schematic illustration of $p \mathrm{Y}_{\mathrm{ox}} \mathrm{NP}$ construction and $\mathrm{Cu}^{2+}$ sensing. $p \mathrm{Y}_{\mathrm{ox}} \mathrm{NPs}$ form by a combination of oxidation, polymerisation, and self-assembly in alkaline conditions. The purple arrows represent ultraviolet light, and the green 'thunder' represents fluorescence as excited by ultraviolet light. The blue fluorescence of $p Y_{\text {ox }}$ NPs can apply to $\mathrm{Cu}^{2+}$ sensing based-on an efficient quenching mechanism 


\section{MATERIALS AND METHODS}

\section{MATERIALS AND APPARATUSES}

L-Tyrosine and all other reagents such as $\mathrm{CuCl}_{2}, \mathrm{CaCl}_{2}$, $\mathrm{CdCl}_{2}, \mathrm{MgCl}_{2}, \mathrm{LiC}_{1}, \mathrm{NiCl}_{2}, \mathrm{PbCl}_{2}, \mathrm{ZnCl}_{2}, \mathrm{NaCl}$, and $\mathrm{AgNO}_{3}$ metal ions were supplied by Aladdin Reagent Co. Ltd. (Shanghai, China); $\mathrm{NaOH}, \mathrm{HCl}$ was supplied by Beijing Chemical Reagent Co. Ltd. (Beijing, China). All the metal ion compounds are analytical reagent grade without further purification. Deionized water (18.2 $\mathrm{M} \Omega \cdot \mathrm{cm}$ ) used for all experiments was made from a Milli-Q system (Millipore, Bedford, USA). All solvents were deionized water except for special descriptions. UVVis spectrometer (U-2900, Hitachi, Japan), Fluorescence spectrometer (Fluorolog®-MAX 4, Horiba, Japan), dynamic light scattering (DLS) equipment (Malvern Zetasizer Nano-ZS90, Malvern Instruments Ltd., UK).

\section{PREPARATION OF $p Y_{o x}$ NPs}

Dissolved $72 \mathrm{mg}$ of tyrosine in $20 \mathrm{~mL}$ of sodium hydroxide $(0.1 \mathrm{M})$ and $20 \mathrm{~mL}$ of hydrochloric acid $(0.1 \mathrm{M})$, respectively. Weighed $7.2 \mathrm{mg}$ of tyrosine and dissolved it in $20 \mathrm{~mL}$ of water, heated it at $80{ }^{\circ} \mathrm{C}$ for condensation and refluxed for $4 \mathrm{~h}$, then stopped heating and continue stirring overnight. After filtration with $0.22 \mu \mathrm{M}$ membrane filters, we got the reserve solution of tyrosine dissolved in sodium hydroxide solution, i.e. synthetic polymerised oxidized Y NPs ( $\left.p \mathrm{Y}_{\text {ox }} \mathrm{NPs}\right)$, tyrosine hydrochloric acid solution reserve solution (Y-HCl), and tyrosine aqueous solution reserve solution $\left(\mathrm{Y}-\mathrm{H}_{2} \mathrm{O}\right)$, which was stored at room temperature. In addition, the particle size was measured by the DLS equipment (DLS), and the absorbance of the solution was measured with the ultraviolet visible spectrometer, the fluorescence spectra was recorded with the fluorescence spectrometer, and the solution fluorescence was observed under the UV lamp.

\section{ASSAYS FOR SENSING $\mathrm{Cu}^{2+}$}

Weighed $85.2 \mathrm{mg}$ of cupric chloride dihydrate dissolved in $5 \mathrm{~mL}$ water to prepare a $\mathrm{Cu}^{2+}$ stock solution $(100 \mathrm{mM})$, then gradually dilute it to obtain a concentration gradient as $10000,7500,5000,2500,1000,750,500,250,100$, $75,50,25 \mu \mathrm{M}$. Took $100 \mu \mathrm{L}$ of each gradient solution into the centrifuge tube and added $900 \mu \mathrm{L}$ of oxidized tyrosine $\left(\mathrm{Y}_{\mathrm{ox}}\right)$ stock solution, respectively, mixed and standed for $2 \mathrm{~h}$. To measure fluorescence, the samples were excited at $365 \mathrm{~nm}$, and the standard curve was made by plotting the fluorescence intensity at $463 \mathrm{~nm}$ against $\mathrm{Cu}^{2+}$ concentration. In order to determine the specificity of the method, we designed the interference experiment of other metal ions, and prepared metal ions solutions, such as: $\mathrm{Zn}^{2+}, \mathrm{Pb}^{2+}, \mathrm{Ni}^{+}, \mathrm{Na}^{+}, \mathrm{Mg}^{2+}, \mathrm{Li}^{+}, \mathrm{Cd}^{2+}, \mathrm{Ca}^{2+}, \mathrm{Ag}^{+}$ $(100 \mu \mathrm{m})$. By treating these ions with the same method for $\mathrm{Cu}^{2+}$, we can analyze the 'interference' of these ions on fluorescence. The limit of detection (LOD) was calculated according to the $3 \sigma$ method.

\section{RESULTS AND DISCUSSION}

\section{CHARACTERIZATION OF $p \mathrm{Y}_{\text {ox }}$ NPs}

To study the physicochemical properties, we obtained three Y-containing stock solutions, termed as $p \mathrm{Y}_{\text {ox }} \mathrm{NPs}$, $\mathrm{Y}-\mathrm{HCl}$, and $\mathrm{Y}_{-} \mathrm{H}_{2} \mathrm{O}$. The stock solution of $p \mathrm{Y}_{\mathrm{ox}} \mathrm{NPs}$ exhibits yellow colour, while stock solutions of $\mathrm{Y}-\mathrm{H}_{2} \mathrm{O}$ and $\mathrm{Y}-\mathrm{HCl}$ are colourless. It is worth noting that the concentration of $\mathrm{Y}$ in water cannot be comparable to those in $\mathrm{HCl}$ and $\mathrm{NaOH}$ solutions, so to prepare $\mathrm{Y}-\mathrm{H}_{2} \mathrm{O}$ solution must be under the conditions of both heating and stirring overnight, the low water-solubility of $\mathrm{Y}$ is due to its natural chemical property ( $\mathrm{Li}$ et al. 2019). In contrast, the preparation of $\mathrm{Y}-\mathrm{NaOH}$ solution requires neither heating nor stirring overnight. For the other two solutions $\mathrm{Y}-\mathrm{H}_{2} \mathrm{O}$ and $\mathrm{Y}-\mathrm{HCl}$, a single peak at $274 \mathrm{~nm}$ shows in their absorption spectra (Figure 2(A)), indicating that $\mathrm{Y}$ is not oxidized. However, in the alkaline solution, the single absorption peak shifts to $293 \mathrm{~nm}$ and became bigger (Figure 2(A)), indicating the chemical changes of $\mathrm{Y}$ molecules. In terms of solution colour, the unheated $\mathrm{Y}-\mathrm{HCl}$ solution is colourless and transparent, however, $p \mathrm{Y}_{\mathrm{ox}} \mathrm{NPs}$ solution is yellow though still transparent, which could be due to the oxidation of hydroxyl groups on benzene ring under heating conditions, resulting in the change of liquid colour (Figure S1). In terms of molecular structure, deprotonation occurs to $\mathrm{Y}$ in alkaline solutions, producing groups like - $\mathrm{COO}$ - and -NH- (Figure S2), both of which enhance the solubility of Y. The blue fluorescence of pYox was observed using an excitation at $365 \mathrm{~nm}$. The maximum emission peak was found at $463 \mathrm{~nm}$ in alkaline solutions (pYox), but not in the control solutions like Y-H2O, Y-HCL and Y-NaOH (Figure 2B). We speculate that a new additional ring (indoline structure) formed on the benzene ring of Y (Figure S2), creating a novel chromophore which makes the emission wavelength red-shifted (Lee et al. 2016).

According to the principle of fluorescence (Verlag 2006), some ground-state electrons outside the nucleus can be excited by the high energy of light, and then electron transition occurs. When this excited electron returns to the ground state, the energy will be released in the form of radiation to produce fluorescence. But not all energy can be released in the form of radiation, usually a small fragment of energy is released in the form of non-radiation like heat. When a single Y molecule absorbs UV light and its electrons firstly excited to high-energic orbitals and then they return to the ground state, some energy of the excited electrons will inevitably lose in a nonradiative transition way due to the rotational vibration of 

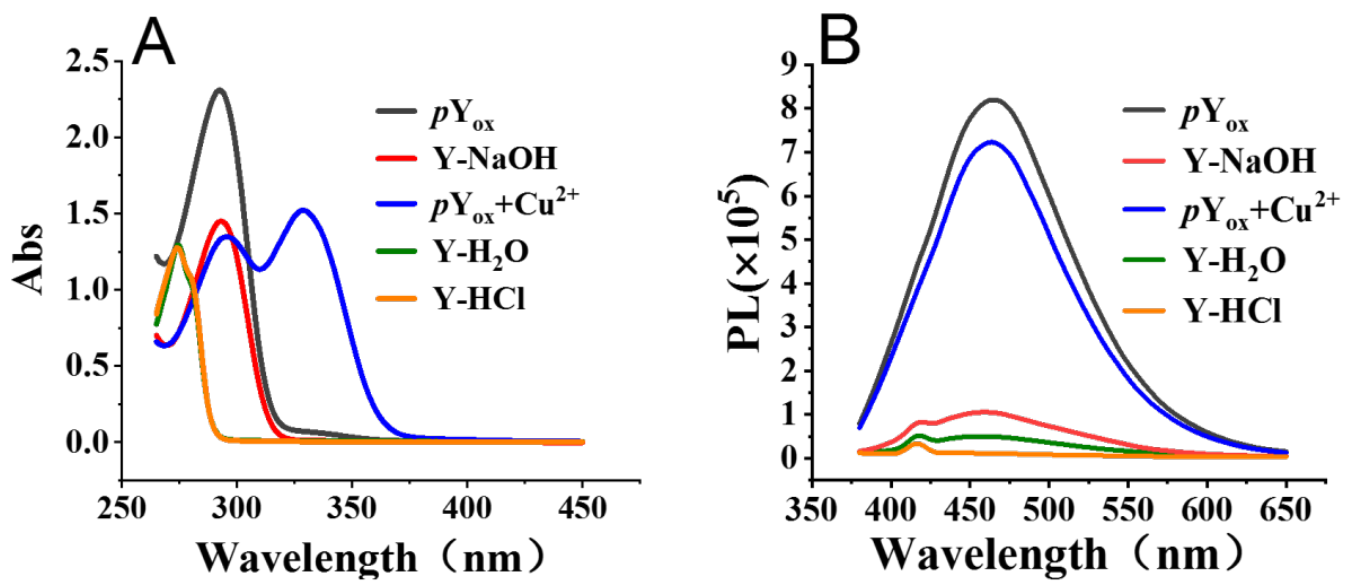

FIGURE 2. Optical characterization of Y under different conditions. Absorption A) and photoluminescence (PL). B) spectra of as-prepared $\mathrm{Y}$ samples in different conditions. $p \mathrm{Y}_{\mathrm{ox}}$, the polymer of oxidized $\mathrm{Y}$; $\mathrm{Y}-\mathrm{NaOH}$, the control solution of $\mathrm{Y}$ dissolved in diluted $\mathrm{NaOH}$ (without heating and reflux); $p \mathrm{Y}_{\mathrm{ox}}+\mathrm{Cu}^{2+}$, polymer of oxidized $\mathrm{Y}$ mixing with $\mathrm{Cu}^{2+} ; \mathrm{Y}_{-} \mathrm{H}_{2} \mathrm{O}, \mathrm{Y}$ just dissolved in water; $\mathrm{Y}-\mathrm{HCl}, \mathrm{Y}$ dissolved in dilute $\mathrm{HCl}$ solution; the detailed preparation can refer to the experimental section

the benzene ring, which will hardly produce fluorescence. Similar to GFP (Tsien 1998), the chromophore of GFP needs a $\beta$-barrel cage to lock its chromophore's rotation to improve its fluorescence quantum yield and meanwhile prevent water from quenching its fluorescence utilizing spatial isolation. After the cyclization and oxidation of $\mathrm{Y}$ residues, new chromophores were formed (Figure S2), which can be verified by the optical changes (Figure 2). After the oxidation and cross-linking of benzene rings (Figure S2), the chromophores were further locked to prevent rotating. All excited electrons should release energy via increased radiation-based transition, thus reduction radiation-based transition, eventually save energy for producing fluorescence (Figure 2) (Ren et al. 2019).

In order to proves that $\mathrm{Y}$ occurred crosslinking and polymerisation, DLS measurement was carried out.
We observed that the hydrodynamic size of $p \mathrm{Y}_{\mathrm{ox}} \mathrm{NPs}$ was about $5 \mathrm{~nm}$, which is with following the normal distribution (Figure 3). If we increased the reflux time, we found that the hydrodynamic size $p \mathrm{Y}_{\text {ox }}$ gradually increased (data not shown), indicating the extent of polymerisation/crosslinking. However, no matter if the reflux time is long or short, the DLS cannot obtain a good result for $\mathrm{Y}$ dissolved in $\mathrm{HCl}(\mathrm{Y}-\mathrm{HCl})$ or water $\left(\mathrm{Y}_{-} \mathrm{H}_{2} \mathrm{O}\right)$. However, because these solutions ( $\mathrm{Y}-\mathrm{HCl}$ and $\mathrm{Y}_{2} \mathrm{H}_{2} \mathrm{O}$ ) are colourless and transparent (Figure S1), indicating that $\mathrm{Y}$ is still dispersed in the solvent as a single molecule. Thus, the molecule is too small to be measured by the current DLS instrument, which further proves that $\mathrm{Y}$ does not occur oxidation and the successive cross-linking/ polymerisation in acidic and neutral solutions.

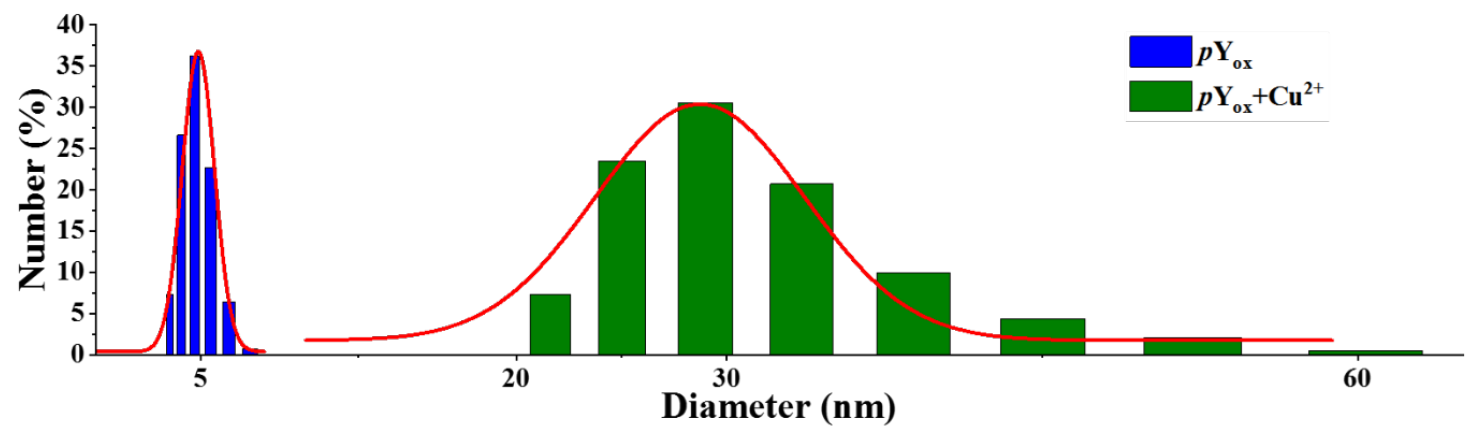

FIGURE 3. DLS analysis of the hydrodynamic size distribution of $p \mathrm{Y}_{\mathrm{ox}}$ before and after mixing with copper ions. The blue and green histograms represent $p \mathrm{Y}_{\mathrm{ox}}$ and $p \mathrm{Y}_{\mathrm{ox}}+\mathrm{Cu}^{2+}$ samples, respectively. The red lines are the single peak fitting 


\section{ASSAYS FOR SENSING $\mathrm{Cu}^{2+}$}

$p \mathrm{Y}_{\text {ox }}$ NPs emit blue fluorescence, which can be efficiently quenched upon binding with $\mathrm{Cu}^{2+}\left(p \mathrm{Y}_{\text {ox }}+\mathrm{Cu}^{2+}\right.$, Figure 2(B)). The size distribution of $p \mathrm{Y}_{\mathrm{ox}} \mathrm{NPs}+\mathrm{Cu}^{2+}$ is measured to about $30 \mathrm{~nm}$, which is significantly larger than that of $p \mathrm{Y}_{\text {ox }} \mathrm{NPs}$ themselves (Figure 3). With a new absorption peak appearing at $329 \mathrm{~nm}$, we deduce that the cation ions can strongly coordinate with $p \mathrm{Y}_{\text {ox }}$ NPs (Figure 2(A)). When the $\mathrm{Cu}^{2+}$ concentration is within the range of $25 \mu \mathrm{M}-10 \mathrm{mM}$, the fluorescence of $p \mathrm{Y}_{\mathrm{ox}} \mathrm{NPs}$ at $463 \mathrm{~nm}$ decreases along with the increasing of $\mathrm{Cu}^{2+}$ concentration (Figure 4(A)). The plot of fluorescence intensity against the concentration of $\mathrm{Cu}^{2+}$ shows a shape of decay curve, so it was well fitted to an exponential decay function (Figure 4(B)) with the formula shown in (1) and (2).

$$
\begin{aligned}
y= & 2.5 \times 10^{5}-3.4 \times 10^{4} \times e^{\frac{t}{1.3 \times 10^{2}}}+2.5 \times 10^{5} \times e^{\frac{t}{1.0 \times 10^{3}}} \\
& +3.4 \times 10^{5} \times e^{\frac{t}{4.9 \times 10^{3}}}
\end{aligned}
$$

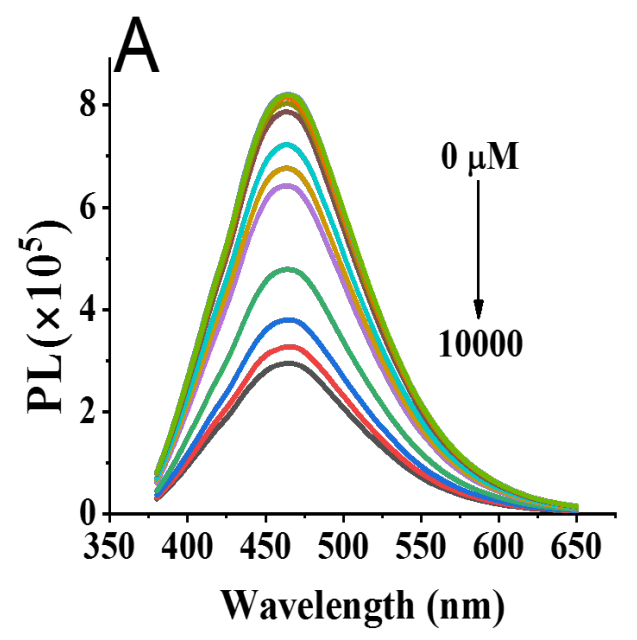

$$
t=0.6-x
$$

When $\mathrm{Cu}^{2+}$ concentration ranges from $40 \mu \mathrm{M}$ to $1 \mathrm{mM}$, the fluorescence intensity of $p \mathrm{Y}_{\mathrm{ox}} \mathrm{NPs}$ changes linearly with $\mathrm{Cu}^{2+}$ concentration (Figure 5(A), S3(A)), with a linear equation, as shown in (3).

$$
y=-209.44 x+8.6 \times 10^{5}\left(R^{2}=0.9916\right)
$$

The limit of detection (LOD) calculated by $3 \sigma$ rule is $37.26 \mathrm{mM}$, which represents a relatively high sensitivity to $\mathrm{Cu}^{2+}$. In addition, the $\mathrm{Cu}^{2+}$ quenching of the fluorescence of $p \mathrm{Y}_{\mathrm{ox}} \mathrm{NPs}$ is also consistent with the Stern-Volmer equation (Figure S2), indicating a static quenching mechanism further proves the robust coordination between $p \mathrm{Y}_{\mathrm{ox}} \mathrm{NPs}$ and $\mathrm{Cu}^{2+}$.

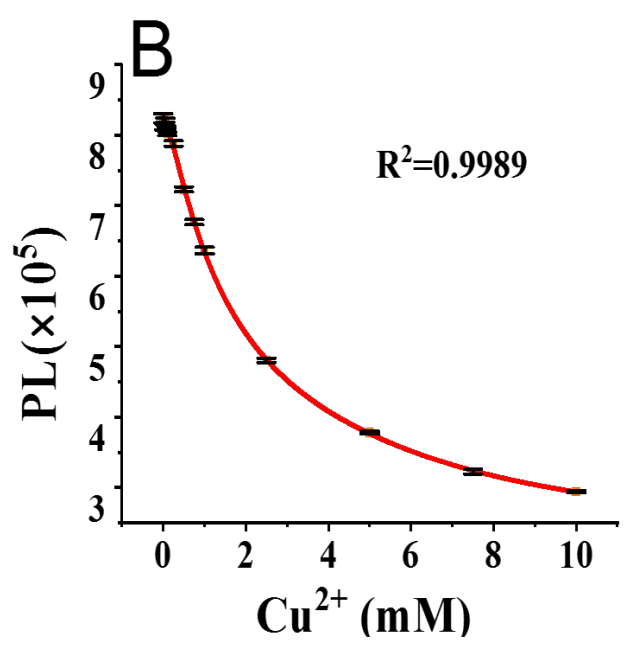

FIGURE 4. Sensing assays A) Fluorescence spectra of $p Y_{\text {ox }}$ NPs solutions mixed with gradient concentrations of $\mathrm{Cu}^{2+}$ as indicated in the figure (from upper to bottom, the concentration is increased), B) A plot of $p \mathrm{Y}_{\text {ox }} \mathrm{NPs}$ fluorescence intensity at $463 \mathrm{~nm}$ against $\mathrm{Cu}^{2+}$ concentration (black dots), and the corresponding fitting with a correlation coefficient (R2) of 0.9989

Taking other metal ions and $\mathrm{Cu}^{2+}$ of the same concentration for a comparison measurement, we analysed the interference of other metal ions on this method. The interference experiments of various common metal ions $(100 \mu \mathrm{M})$ on the detection system showed that only $\mathrm{Cu}^{2+}$ had the best fluorescence quenching effect on $p \mathrm{Y}_{\mathrm{ox}} \mathrm{NP}$ solution, while the other cations showed little effects on $p \mathrm{Y}_{\text {ox }} \mathrm{NPs}$ solution (Figure 5(B)), indicating a relatively high specificity for binding with $\mathrm{Cu}^{2+}$.
Compared with other aromatic amino acids as fluorescent chromophores, the dopa quinone formed by oxidation of $Y$ residues has redundant lone-pair electrons and is more likely to chelate metal ions (Lee \& Lee 2015). Moreover, after crosslinking/polymerisation, the fluorescence of $p \mathrm{Y}_{\mathrm{ox}}$ solution exhibited a redshift, which could be due to the interactions of both hydrophobicity and $\pi-\pi$ stacking. It is found that $\mathrm{Cu}^{2+}$ cannot make the $p \mathrm{Y}_{\text {ox }}$ NPs aggregate and thus increase their hydrodynamic 
sizes, but also strongly quench their fluorescence, which could be explained by the negative value of the Gibbs free energy $\Delta \mathrm{G}(-16.27 \mathrm{~kJ} / \mathrm{mol}$, see $\mathrm{SI})$, indicating a spontaneous binding (Liu et al. 2015; Yuan et al. 2016; Zhong et al. 2014) between $\mathrm{Cu}^{2+}$ and $p \mathrm{Y}_{\text {ox }} \mathrm{NPs}$.
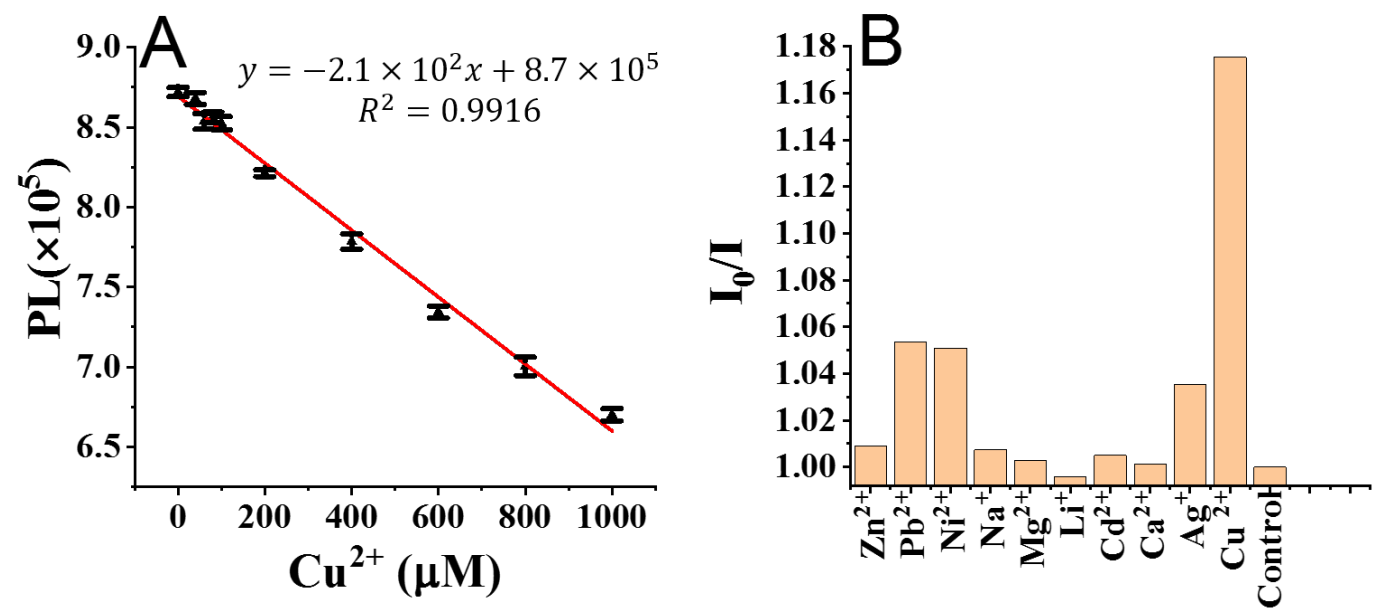

FIGURE 5. The optimized concentration ranges for sensing $\mathrm{Cu}^{2+}$ and the selectivity comparison of cations A) The plot of $p \mathrm{Y}_{\text {ox }} \mathrm{NP}$ fluorescence intensity at $463 \mathrm{~nm}$ against the $\mathrm{Cu}^{2+}$ concentration (black dots), and the corresponding linear fitting (red line) with a function and the correlation coefficient (R2), B) The selectivity or interference test of cations for $p \mathrm{Y}_{\mathrm{ox}} \mathrm{NPs}$-based sensor. I0 and I represent the $463 \mathrm{~nm}$ fluorescence intensity of $p \mathrm{Y}_{\mathrm{ox}} \mathrm{NPs}$ in the absence and presence of cations

At last, we also assessed the reliability of the current developed approach, and the results are displayed in Table 1. By analysing the recoveries of $\mathrm{Cu}^{2+}$, which varied from $104 \%$ to $112 \%$ with a relative standard deviation (RSD) ranging from 0.36 to 0.90 , we think the results achieved by our method are in good agreement with the real values, indicating that the current sensing technology reported in this article are robust and reliable for sensing $\mathrm{Cu}^{2+}$ in aqueous solutions.

TABLE 1 . Reliability evaluation of the $\mathrm{Cu}^{2+}$ sensing

\begin{tabular}{lllll}
\hline $\mathrm{Cu}^{2+}$ samples & Added $\mathrm{Cu}^{2+}(\mu \mathrm{M})$ & Detected $\mathrm{Cu}^{2+}(\mu \mathrm{M})$ & $\operatorname{RSD}(\mathrm{n}=5, \%)$ & Recovery $(\%)$ \\
\hline 1 & 250 & 272.06 & 0.90 & 108.82 \\
2 & 500 & 559.53 & 0.36 & 111.91 \\
3 & 750 & 780.44 & 0.39 & 104.06 \\
\hline
\end{tabular}

\section{CONCLUSION}

New technologies can inevitably innovate the living ways such as the clinical diagnosis in the contemporary era. The current fluorescent copper ion nanosensor was constructed via the combination of oxidation, polymerisation and self-assembly of single $\mathrm{Y}$ residues in basic conditions. We envision that co-assembling of more amino acids might create more versatile functional nanostructures, which hold great potential in bio-labeling/ imaging/sensing, and even therapy for diseases. We also 
believe this study will inspire scientists to open a new researching orientation based on the combination and coassembling of amino acids via an artificial evolution way.

\section{ACKNOWLEDGEMENTS}

The following programs and foundations supported this work: the University Scientific Research Project of Inner Mongolia Autonomous Region (NJZC17267), the Program Funded by University for Fostering Distinguished Young Scholars, the National Natural Science Foundation of China (No.51763019, U1832125), the Grassland Talents Program of Inner Mongolia Autonomous Region, the Distinguished Young Scholars Foundation of Inner Mongolia Autonomous Region, and the Young Leading Talents of Science and Technology Program of Inner Mongolia Autonomous Region.

\section{REFERENCES}

Baker, Z.N., Cobine, P.A. \& Leary, S.C. 2017. The mitochondrion: A central architect of copper homeostasis. Metallomics 9(11): 1501-1512.

Bartesaghi, S. \& Radi, R. 2018. Fundamentals on the biochemistry of peroxynitrite and protein tyrosine nitration. Redox Biol. 14: 618-625.

Bergwerff, C.E., Luman, M., Blom, H.J. \& Oosterlaan, J. 2016. No tryptophan, tyrosine and phenylalanine abnormalities in children with attention-deficit/hyperactivity disorder. PLoS ONE 11(3): e0151100.

Brewer, G.J. 2012. Copper excess, zinc deficiency, and cognition loss in Alzheimer's disease. Biofactors 38(2): 107-113.

Bulcke, F., Dringen, R. \& Scheiber, I.F. 2017. Neurotoxicity of copper. Adv. Neurobiol. 18: 313-343.

Contino, A., Maccarrone, G., Zimbone, M., Reitano, R., Musumeci, P., Calcagno, L. \& Oliveri, I.P. 2016. Tyrosine capped silver nanoparticles: A new fluorescent sensor for the quantitative determination of copper(ii) and cobalt(ii) ions. J. Colloid Interface Sci. 462: 216-222.

Ding, D., Guerette, P.A., Fu, J., Zhang, L., Irvine, S.A. \& Miserez, A. 2015. From soft self-healing gels to stiff films in suckerinbased materials through modulation of crosslink density and beta-sheet content. Adv. Mater. 27(26): 3953-3961.

Ghasemian, E., Naghoni, A., Tabaraie, B. \& Tabaraie, T. 2012. In vitro susceptibility of filamentous fungi to copper nanoparticles assessed by rapid xtt colorimetry and agar dilution method. J. Mycol. Med. 22(4): 322-328.

Ghosh, D. \& Chattopadhyay, N. 2015. Gold and silver nanoparticles based super quenching of fluorescence: A review. Journal of Luminescence 160: 223-232.

Guo, J., Ramachandran, S., Zhong, R., Lal, R. \& Zhang, F. 2019. Generating cyan fluorescence with de novo tripeptides: An in vitro mutation study on the role of single amino acid residues and their sequence. ChemBioChem 20(18): 2324-2330.

Hemmateenejad, B. \& Yousefinejad, S. 2013. Interaction study of human serum albumin and ZNS nanoparticles using fluorescence spectrometry. Journal of Molecular Structure 1037: 317-322.
Kamaraj, B. \& Purohit, R. 2014. Mutational analysis of oculocutaneous albinism: A compact review. Biomed. Res. Int. 2014: 905472.

Kusunuru, A.K., Tatina, M., Yousuf, S.K. \& Mukherjee, D. 2013. Copper mediated stereoselective synthesis of c-glycosides from unactivated alkynes. Chem. Comm. 49(86): 1015410156.

Lee, C. \& Lee, S.Y. 2015. Mussel-inspired bolaamphiphile sticky self-assemblies for the preparation of magnetic nanoparticles. Colloids Surf B Biointerfaces 127: 89-95.

Lee, S., Liang, R., Voth, G.A. \& Swanson, J.M. 2016. Computationally efficient multiscale reactive molecular dynamics to describe amino acid deprotonation in proteins. J. Chem. Theory Comput. 12(2): 879-891.

Li, M., Fu, Y. \& Jin, L. 2017. A dual-signal sensing system based on organic dyes-LDHs film for fluorescence detection of cysteine. Dalton Trans 46(22): 7284-7290.

Li, X., Li, K., Farajtabar, A., He, Y., Chen, G. \& Zhao, H. 2019. Solubility of d-tryptophan and l-tyrosine in several organic solvents: Determination and solvent effect. Journal of Chemical \& Engineering Data 64(7): 3164-3169.

Lin, Y.W., Huang, C.C. \& Chang, H.T. 2011. Gold nanoparticle probes for the detection of mercury, lead and copper ions. Analyst 136(5): 863-871.

Liu, Y-S., Zhang, P., Zhong, R., Bai, Z-J., Guo, J., Zhao, G-F. \& Zhang, F. 2015. Fluorimetric study on the interaction between fluoresceinamine and bovine serum albumin. Nuclear Science and Techniques 26(3): 030505.

Nieder, R., Benbi, D.K. \& Reichl, F.X. 2018. Microelements and their role in human health. In Soil Components and Human Health. Springer Netherlands, Dordrecht. pp. 317-374.

Parmar, A.S., James, J.K., Grisham, D.R., Pike, D.H. \& Nanda, V. 2016. Dissecting electrostatic contributions to folding and self-assembly using designed multicomponent peptide systems. J. Am. Chem. Soc. 138(13): 4362-4367.

Pinotsi, D., Grisanti, L., Mahou, P., Gebauer, R., Kaminski, C.F., Hassanali, A. \& Kaminski Schierle, G.S. 2016. Proton transfer and structure-specific fluorescence in hydrogen bond-rich protein structures. J. Am. Chem. Soc. 138(9): 3046-3057.

Ren, X., Zou, Q., Yuan, C., Chang, R., Xing, R. \& Yan, X. 2019. Frontispiece: The dominant role of oxygen in modulating the chemical evolution pathways of tyrosine in peptides: Dityrosine or melanin. Angewandte Chemie International Edition 58(18): 5872-5876.

Teale, F.W. \& Weber, G. 1957. Ultraviolet fluorescence of the aromatic amino acids. Biochem. J. 65(3): 476-482.

Tsien, R.Y. 1998. The green fluorescent protein. Annu. Rev. Biochem. 67: 509-544.

Verlag, S. 2006. Principles of Fluorescence Spectroscopy. New York: Plenum Press.

White, B.R. \& Holcombe, J.A. 2007. Fluorescent peptide sensor for the selective detection of cu2+. Talanta 71(5): 2015-2020.

Xu, X., Daniel, W.L., Wei, W. \& Mirkin, C.A. 2010. Colorimetric $\left.\mathrm{Cu}^{2+}\right)$ detection using DNA-modified gold-nanoparticle aggregates as probes and click chemistry. Small 6(5): 623626.

Yu, H., Wang, D., Zou, L., Zhang, Z., Xu, H., Zhu, F., Ren, X., Xu, B., Yuan, J., Liu, J., Spencer, P.S. \& Yang, X. 2018. Proteomic alterations of brain subcellular organelles caused 
by low-dose copper exposure: Implication for Alzheimer's disease. Archives of Toxicology 92(4): 1363-1382.

Yuan, M., Zhong, R., Yun, X., Hou, J., Du, Q., Zhao, G. \& Zhang, F. 2016. A fluorimetric study on the interaction between a Trp-containing beta-strand peptide and amphiphilic polymercoated gold nanoparticles. Luminescence 31(1): 47-53.

Zhong, R., Liu, Y., Zhang, P., Liu, J., Zhao, G. \& Zhang, F. 2014. Discrete nanoparticle-BSA conjugates manipulated by hydrophobic interaction. ACS Applied Materials \& Interfaces 6(22): 19465-19470.

Jiaqi Lian, Xiang Ji1* \& Feng Zhang*

School of Life Science and Technology

Inner Mongolia University of Science and Technology

Baotou 014010

P. R. China

Jiaqi Lian, Pandeng Miao, Na Li, Abdul Jamil Khan \& Feng Zhang*

Biomedical Nanocenter, School of Life Science

Inner Mongolia Agricultural University

Hohhot 010018

P. R. China
Pandeng Miao \& Na Li

Terahertz Technology Innovation Research Institute Shanghai Key Laboratory of Modern Optical System Terahertz Science Cooperative Innovation Center University of Shanghai for Science and Technology 516 Jungong Road, Shanghai 200093 P. R. China

Feng Zhang*

Key Laboratory of Oral Medicine Guangzhou Institute of Oral Disease

Stomatology Hospital, Department of Biomedical Engineering School of Basic Medical Sciences

Guangzhou Medical University

Guangzhou 511436

P. R. China

*Corresponding author; email: jixiang@imust.cn

Received: 17 January 2020

Accepted: 8 June 2020 


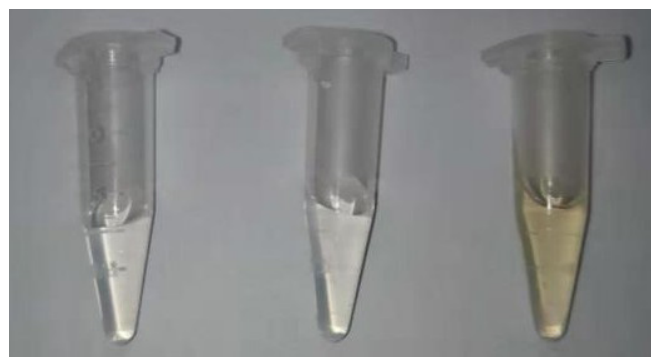

FIGURE S1. The color comparison of Y-HCl, Y-H O and $p \mathrm{Y}_{\text {ox }}$ solutions (from left to right) under daylight<smiles>N[C@@H](Cc1ccc(O)cc1)C(=O)NOc1ccc(O)cc1</smiles>
Y

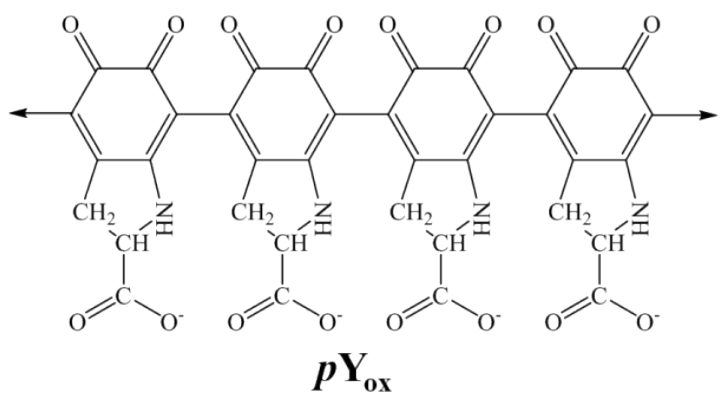

cyclization<smiles>O=C(O)C1Cc2ccc(O)cc2N1</smiles>

$\mathrm{Y}-\mathrm{NaOH}$

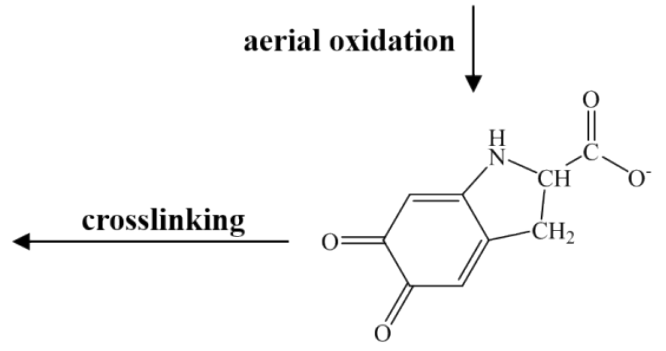

$\mathbf{Y}_{\text {ox }}$-monomer

FIGURE S2. A chemical evolution procedure of $Y$ in alkaline solutions. In sodium hydroxide solution, $\mathrm{Y}$ can be firstly deprotonated to produce imine group $\left(-\mathrm{NH}^{-}\right)$, deprotonated hydroxyl group $\left(-\mathrm{O}^{-}\right)$and carboxylic group (-COO-$)$, and then the imine group and benzene ring can cyclize to form a two-ring structure (indoline group, whose absorption peak shifts to red region), then hydroxyl groups are further oxidized to form O-benzoquinone ( $\left.\mathrm{Y}_{\mathrm{Ox}}\right)$, which eventually polymerize to $p \mathrm{Y}_{\mathrm{OX}}$ by cross-linking reaction (Ding et al. 2015)
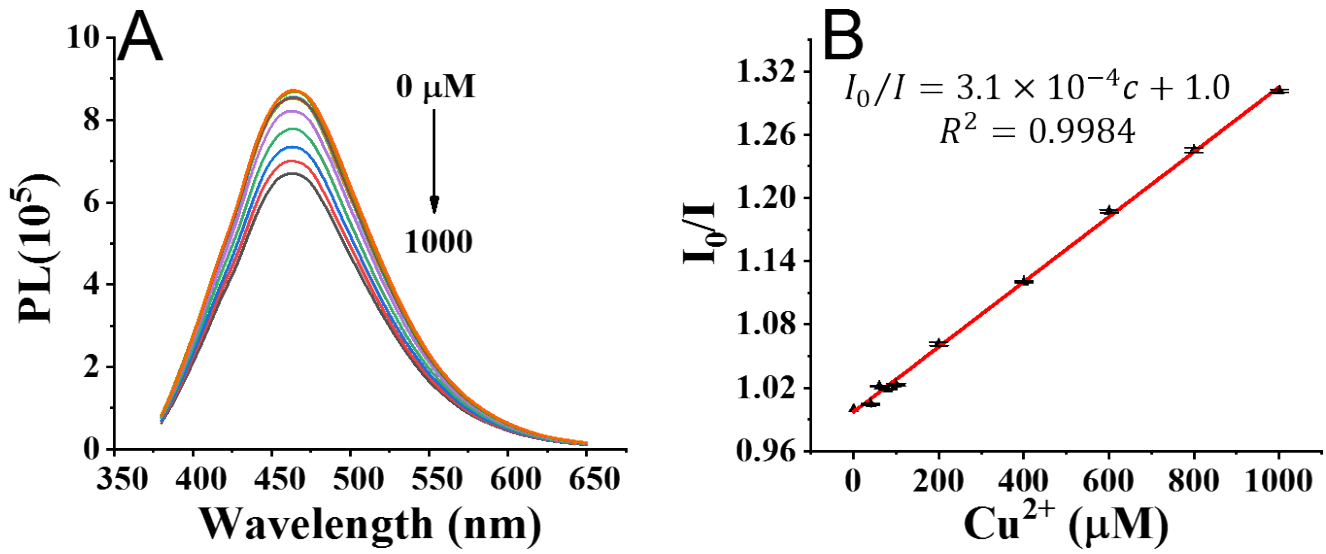

FIGURE S3. The assays of $p \mathrm{Y}_{\mathrm{OX}} \mathrm{NPs}$, fluorescence quenched by $\mathrm{Cu}^{2+} \mathrm{A}$ ). The steady-state fluorescence spectra of $p Y_{O X} N P s$ mixed with various concentrations of $\mathrm{Cu}^{2+}$ ranging from 0 to $1000 \mu \mathrm{M}$ as indicated by the arrow in the figure. The spectra were recorded at $298 \mathrm{~K}$ with an excitation of $365 \mathrm{~nm}, \mathrm{~B}$ ) The Stern-Volmer plot (black dots) for the fluorescence quenching ratio of $p \mathrm{Y}_{\mathrm{OX}}$ against $\mathrm{Cu}^{2+}$ ion (black dots) and the corresponding linear fitting (red line). I0 and I represent the fluorescence intensity of the $p \mathrm{Y}_{\mathrm{OX}} \mathrm{NP}$ solution before and after mixing with different concentrated $\mathrm{Cu}^{2+}$ 


\section{FLUORESCENCE QUENCHING AND THERMODYNAMICS}

In order to figure out the mechanism how $\mathrm{Cu}^{2+}$ can quench $p \mathrm{Y}_{\text {ox }} \mathrm{NPs}$, we studied the thermodynamics of this binding system, in which the quencher is $\mathrm{Cu}^{2+}$. According to the Stern-Volmer equation (Ghosh \& Chattopadhyay 2015) (1), in which I0 and I are the fluorescence intensities in presence and absence of quenchers, respectively. [Q], $\mathrm{K}_{\mathrm{SV}}$ and $\tau_{0}$ are the concentration of quencher, the quenching constant of Stern-Volmer and the life time of fluorescence, respectively.

$$
\begin{aligned}
& \underline{I 0}=K_{S V}[Q]+1 \\
& K_{S V}=K_{q} \times \tau_{0}
\end{aligned}
$$

Generally, the quenching constant $K_{\mathrm{q}}$ is used to better describe this process. And all the $\tau_{0}$ of biomolecules can be considered as $10^{-8} \mathrm{~s}$, therefore, if using the quenching constant $\left(K_{q},(2)\right)$ to replace $K_{S V}$ in (1), we can obtain $K_{S V}$ $=3.1 \times 10^{2} M^{-1}$ and $K_{q}=3.1 \times 10^{10} M^{-1} . S^{-1}$. Because the
$K_{\mathrm{q}}$ is bigger than the diffusion-controlled limit (normally near $\left.1 \times 10^{10} M^{-1} \cdot S^{-1}\right)$, therefore, we think $p Y_{\text {ox }}$ NPs and $\mathrm{Cu}^{2+}$ involve static binding.

In order to verify this reaction can occur spontaneously, we also calculate the Gibbs free energy $\Delta \mathrm{G}$ (Hemmateenejad \& Yousefinejad 2013). By using the Hill equation (S3) in which $I_{s a t}, \eta$ and $K_{\alpha}$ refer to the fluorescence intensity of $\mathrm{pY}_{\mathrm{ox}} \mathrm{NPs}$ mixed with a saturated amount of $\mathrm{Cu}^{2}+$, Hill coefficient and the binding constant, respectively.

$$
\log [I 0-I I-I s a t]=\log K_{a}+n \log [Q]
$$

The $K_{\mathrm{a}}$ was calculated to $7.1 \times 10^{2}\left(\mathrm{M}^{-1}\right)$, with which the $\Delta G$ can be calculated to $-1.6 \times 10^{1} \mathrm{~kJ}^{\mathrm{m}} \mathrm{mol}^{-1}$

$$
\Delta G=-R T \ln K_{\mathrm{a}}
$$

Because the $\Delta G<0$, therefore, the binding between $\mathrm{Cu}^{2+}$ and $p \mathrm{Y}_{\text {ox }}$ NPs should be spontaneous. 